\title{
The occurrence of the epiphytic diatom Lemnicola hungarica on different European Lemnaceae species
}

\author{
Krisztina BUCZKÓ
}

Department of Botany, Hungarian Natural History Museum H-1476, Budapest Pf. 222, Hungary

\begin{abstract}
The substrate specificity of Lemnicola hungarica (Grunow) Round et P.W. Basson was studied on five Lemnaceae species using material from the Herbarium Generale of the Hungarian Natural History Museum. Diatom assemblages inhabiting Lemna minor, Lemna gibba, Spirodela polyrhiza and Wolffia arrhiza were dominated by Lemnicola hungarica, in contrast to assembladges on Lemna trisulca dominated by Cocconeis placentula. An initial or post-initial cell of Lemnicola hungarica has been found in the studied material.
\end{abstract}

Key words: attached diatoms, epiphyton, substrate specificity, Lemnicola, Lemnaceae

\section{Introduction}

Lemnicola hungarica (Grunow) Round et P.W. Basson is a common, widespread diatom, occurring all over the World. Sometimes it is very abundant in biofilms formed on various submersed objects in freshwaters.

In terms of its general appearance Lemnicola hungarica is a very characteristic species, well recognisable especially with its raphe valve. Maybe its most characteristic feature is the thickened, usually asymmetric central stauros on the raphe valve, which reaches the margin. The stauros is absent or very reduced on the rapheless valva. The striae are biseriate, and the distal raphe ends curve in opposite directions. These features can only be well seen on SEM pictures. The shape of the valves are linear-elliptical-lanceolate, with broadly rounded ends.

Only a few diatoms are known to live in specific habitats. One of them is Lemnicola hungarica that, according to the literature, is typically attached to the roots of the common duckweed (Lemna minor). Lemnicola hungarica was described from Lake Balaton (Hungary) as Achnanthidium hungaricum in 1863 by GRUNOW. Already in the original description of the species it was noted that it's habitat preference was "in lacunis parvis inter radicula Lemnarum".

Later (1930) HUSTEDT commented on the occurrence of Achnanthidium hungarica as "anscheinend mit Vorliebe an Lemna". This conspicuous coexistence of Achnanthidium hungaricum and its Lemnaceae hosts was probably one of the main reasons for erecting and naming the monospecific genus Lemnicola by ROUND and BASSON (1997). In 1993 GOLDSBOROUGH presented a complex survey on the ecology of common duckweed epiphytes, including Lemnicola hungarica.

Additional details, including ultra-structure, plastid morphology and ecology of Lemnicola hungarica are discussed in GARCIA \& FONSECA DE SOUZA (2006). They also mention the coexistence of this diatom and some unnamed floating plants, without any further information about the host specificity of Lemnicola hungarica.

It has been unclear whether every duckweed species could support the populations of Lemnicola hungarica or it is Lemna minor that lives in coexistence with it? For studying the distribution of Lemnicola on Lemnaceae species first we had to find duckweed populations containing a single species. In most cases the species of Lemnaceae can only be collected in an association that is the thick, floating mats of duckweed containing several Lemnaceae species. Consequently, such composite samples are not suitable for studying host preferences. However, different exsiccate materials could provide a good possibility to answer questions on this matter.

\section{Material and methods}

Five species of Lemnaceae (Lemna minor, L. gibba, L. trisulca, Sirodela polyrrhiza, and Wolffia arrhiza) with specimens originating from various countries 
and preserved in the herbarium of the Hungarian Natural History Museum (BP) were studied (Fig. 1., Tab. 1.).

Altogether 18 samples were analysed. The samples were treated with hot $\mathrm{H}_{2} \mathrm{O}_{2}$, to eliminate organic material, including all the tissues of Lemnaceae. The cleaned material was mounted in Zrax (refractive index is 1.7). Relative abundances of diatoms were calculated after counting 400 valves. For light microscope analysis a LEICA DM LB2 was used (100 X HCX PLAN APO, and Fujifilm Digital
Camera FinePix S2 Pro). Scanning electron microscopy was performed with a Hitachi S-2600N. We followed the nomenclature of KRAMMER \& LANGE-BERTALOT (1986-1991) and ROUND and BASSON (1997).

Standardized Principal Components Analysis (PCA) was carried out with the selected data by the program package SYN-TAX2000 (PODANI 2001). The taxa that occurred in more than the $20 \%$ of samples were taken into account in the PCA analysis.

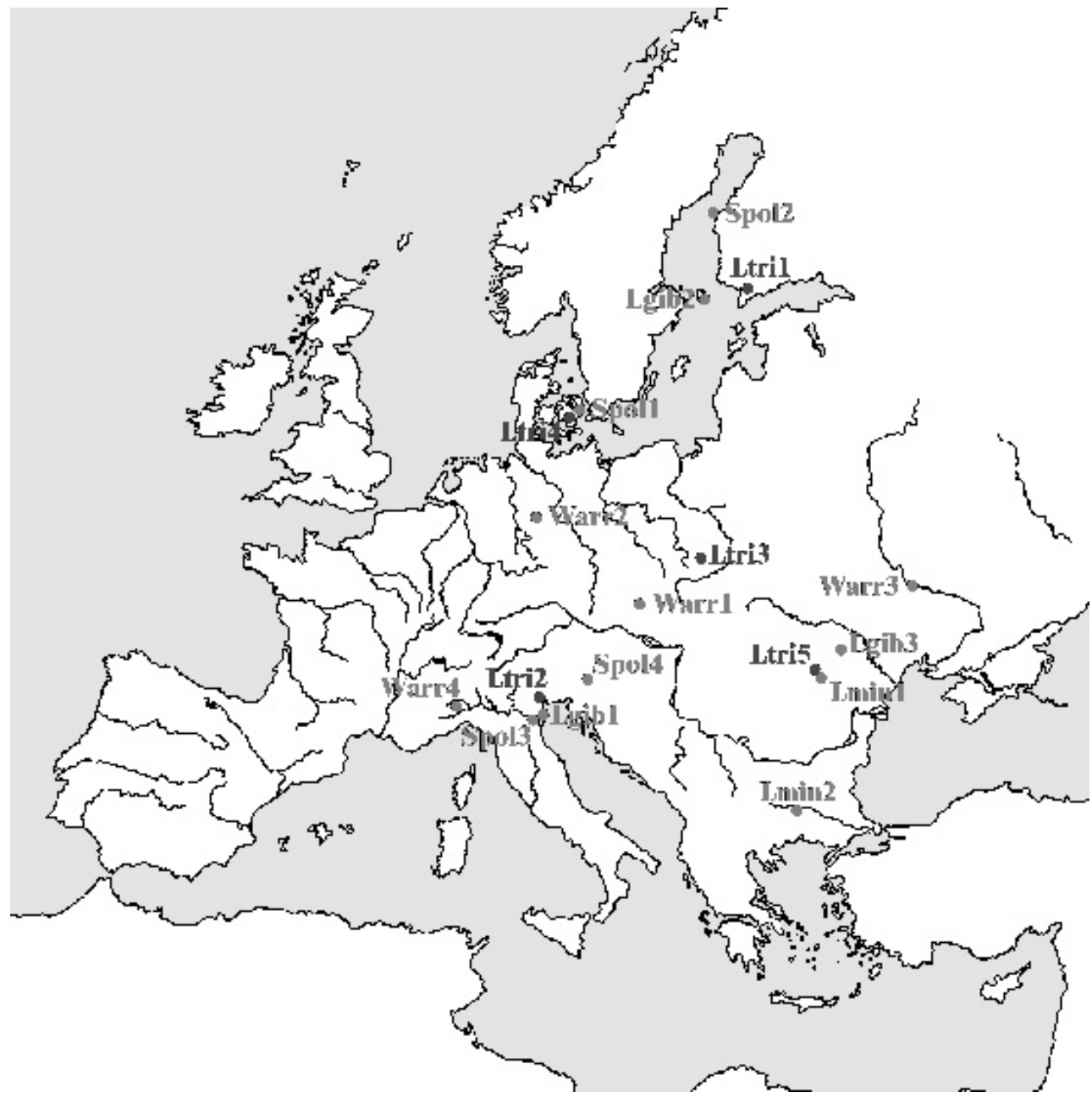

Fig. 1. Locations of the studied samples in different countries of Europe (Ltri - Lemna trisulca, Lgib - Lemna gibba, Lmin Lemna minor, Spol - Sirodela polyrhiza, Warr - Wolffia arrhiza).

\section{Results and discussion}

Lemnicola hungarica was found in every sample, but its abundance varied over a wide range: there were samples where the occurrence was at floristic detection level, whilst in other samples the species was dominant (99\%). The morphological variability of Lemnicola in the studied samples is presented on Fig. 2 and Fig. 3.

During the study only 47 taxa could be distinguished. The dominant diatoms on different Lemnaceae species were, Lemnicola hungarica (Grunow) Round et P.W. Basson Cocconeis placentula Ehrenberg, Achnantidium minutissimum (Kütz.) Czarnecki, Gomphonema 
parvulum Kützing, Navicula cf. subminuscula Manguin, Amphora veneta Kützing, Nitzschia sp., Gomphonema gracile Ehrenberg, Eunotia bilunaris, (Ehrenberg) Mills, Gomphonema olivaceum (Hornemann) Brébisson, Epithemia adnata (Kützing) Brébisson and Fragilaria sp (Tab. 2.). Only these taxa were taken into consideration in this list that occurred in at least $20 \%$ of the samples.

The dominant and subdominant taxa fit very well with the earlier published duckweed floras (e.g. GoLDSBOROUGH 1993). Lemna minor in Canadian lakes was inhabited by Amphora veneta, Cocconeis placentula, Eunotia bilunaris, Gomphonema parvulum, Epithemia adnata $(\geq 5 \%)$. This floristical similarity may suggest that the diatom assemblages on Lemnaceae are characteristic to theirs hosts. Their spatial and seasonal distribution is also very similar.

In our samples the species richness in individual samples varied between 3 and 12 that is very low (Tab. 2.). The Shannon-Weiner diversity always was less than 3 , generally less than 2 , but its minimum value was 0.13 . The percentage distribution of dominant taxa varied on different Lemanaceae species. Lemnicola hungarica is most abundant on Spirodela, Lemna gibba and Lemna minor. On these hosts more than half of the diatoms cells belonged to Lemnicola hungarica. In the case of Wolffia, Lemnicola is also the characteristic diatom in its coating, but its percentange abundance is less than $50 \%$. Whilst on Lemna trisulca, Lemnicola is just one of the minor taxa, these coatings can be charactised by Cocconeis placentula dominance.

The result of PCA analysis (Fig. 5) has revealed the significance of Cocconeis placentula relative to Lemnicola hungarica. Axis 1 accounts for $68 \%$ of total variance, while the axis 2 , for $15 \%$. Altogether, the first 2 axes account only for $83 \%$ of total variance.

Table 1. List of the samples (Lemnaceae species from Herbarium Generale of Hungarian Natural History Museum). Abbreviations used: i.n. - inventory number of the herbarium sheet (BP), coll. - name of the collector and the date of collecting; t.s. - the text of the label of the herbarium sheet;

\begin{tabular}{|c|c|c|}
\hline Duckweed species & $\begin{array}{l}\text { BP number and } \\
\text { code } \\
\text { i.n.: }\end{array}$ & Detailed (all available) information from the sheets \\
\hline \multirow{4}{*}{$\begin{array}{l}\text { Sirodela polyrrhiza (L.) } \\
\text { Schleid. }\end{array}$} & $\begin{array}{l}515913 \\
\text { Spol1 }\end{array}$ & $\begin{array}{l}\text { coll.: N Jacobsen (15.09.1969); t.s.: Hab. Pond; associated with Lemna minor, } \\
\text { Ranunculus aquatilis, Potamogeton natans, Ceratophyllum demersum. } \\
\text { Zealand: Ermelunden near Lyngby, Copenhagen; exicc.: Museum Botanicum } \\
\text { Hauniense, Plantae Vasculares Danicae Exciccatae. }\end{array}$ \\
\hline & \begin{tabular}{|l|}
474408 \\
Spol2
\end{tabular} & $\begin{array}{l}\text { coll.: W. Laurén - Hj Hjelt (15.09.1969.); t.s.: Ostrobottnia australis, Gamla } \\
\text { Vasa, in aqua stagnante in fossa.; exsicc.: Plantae Finlandiae Exsiccatae } \\
\text { Museo botanico Universitatis Helsingforsiensis distributae. }\end{array}$ \\
\hline & \begin{tabular}{|l}
47394 \\
Spol3
\end{tabular} & $\begin{array}{l}\text { coll.: A. Ferioli (06. 1909.); t.s.: Loc: Aemilia - Ferrara, in aquis leute } \\
\text { fluentibus del Po di Volano et del Canale di Cento; exicc.: Flora Italica } \\
\text { Exsiccata Series II. Adr. Fiori et A Béguinot. }\end{array}$ \\
\hline & \begin{tabular}{|l|}
47409 \\
Spol4
\end{tabular} & $\begin{array}{l}\text { coll.: Zupančič (sine date); t.s.: Carniolia. In stagno ad pagum Bucna vas } \\
\text { prope Rudolfswert, } 200 \text { m. s. m.; exicc.: A. Paulin, Flora Exsiccata } \\
\text { Carniolica. }\end{array}$ \\
\hline \multirow{5}{*}{ Lemna trisulca $\mathbf{L}$. } & $\begin{array}{l}47443 \\
\text { Ltri1 }\end{array}$ & $\begin{array}{l}\text { coll.: Ch. E. Boldt. (05.09.1893.); t.s.: Regio Aboënsis, par. Lojo, Humppila } \\
\text { in lacu Hormasjö, in fundo in aqua } 40 \text { m alta.; exsicc.: Plantae Finlandiae } \\
\text { Exsiccatae Museo botanico Universitatis Helsingforsiensis distributae. }\end{array}$ \\
\hline & \begin{tabular}{|l|}
47444 \\
Ltri2
\end{tabular} & $\begin{array}{l}\text { coll.: A. Béguinot, misit P. A. Saccardo (12.04.1907); t.s.: Venetia - Patarium } \\
\text { (Padova) in piscinis R. horti botanici, copiosa.; exicc.: Flora Italica Exsiccata } \\
\text { Series II. Adr. Fiori et A Béguinot. }\end{array}$ \\
\hline & \begin{tabular}{|l|}
47415 \\
Ltri3
\end{tabular} & $\begin{array}{l}\text { coll.: F. Krawiec (03.07.1935.); t.s.: Poznań, Ostrów Tumski. Martwa odnoga } \\
\text { Warty. In flum. Wartae alveo derelicto.; exicc.: Rośliny Polskie - Planae } \\
\text { Poloniae Exsiccatae. }\end{array}$ \\
\hline & \begin{tabular}{|l|}
301335 \\
Ltri4
\end{tabular} & $\begin{array}{l}\text { coll.: N Jacobsen - J. Svendsen (13.09.1969); t.s.: Hab. bog; ass. with Lemna } \\
\text { minor, Typha angustifolia, Hydrocotyle vulgaris, Drepanocladus aduncus } \\
\text { Zealand Staunstrup Mose, S of Rønnede (T.B.U. Distr. } 39 \text { a); exicc.: Museum } \\
\text { Botanicum Hauniense, Plantae Vasculares Danicae Exciccatae. }\end{array}$ \\
\hline & \begin{tabular}{|l|}
537382 \\
Ltri5
\end{tabular} & $\begin{array}{l}\text { coll.: 10.06.1970.; t.s.: Comm, Tg. Trotus: in palude Rogozdicta Alt. } 260 \\
\text { msm; exicc.: exicc.: Flora Exiccata Districti Bacoviensis (Romania), A } \\
\text { Museo Sientiarum Naturalium Bacoviensis Edita. }\end{array}$ \\
\hline
\end{tabular}




\begin{tabular}{|c|c|c|}
\hline \multicolumn{3}{|l|}{ Cont. Table 1.} \\
\hline \multirow[t]{2}{*}{ Lemna minor $\mathrm{L}$. } & $\begin{array}{l}537121 \\
\text { Lmin } 1\end{array}$ & $\begin{array}{l}\text { coll.: D. Mititelu - N. Barabáş - L. Mititelu (10.06.1970.); t.s.: Comm. } \\
\text { Coțofăneşti: prope pagum Borşani, in lacului silvae Chetriş dicta, intra ass. } \\
\text { Lemno-Utricularietum Soó } 38 \text {, Alt. ca } 250 \text { m.; exicc.: Flora Exiccata Districti } \\
\text { Bacoviensis (Romania), A Museo Sientiarum Naturalium Bacoviensis Edita. }\end{array}$ \\
\hline & $\begin{array}{l}84034 \\
\text { Lmin3 }\end{array}$ & $\begin{array}{l}\text { coll.: N. Vyhodcevski (24.09.1954.); t.s.: Bulgaria australis in aquis } \\
\text { stagnsntibus circa urb. Plovdiv.; exicc.. Institutum Botanicum Academiae } \\
\text { Scientiarum Bulgariae, Plantae Bulgaricae exciccatae Cent. V }\end{array}$ \\
\hline \multirow{3}{*}{ Lemna gibba $\mathbf{L}$. } & $\begin{array}{l}47308 \\
\text { Lgib1 }\end{array}$ & $\begin{array}{l}\text { coll.: A Ferioli (06.1909.); t.s.: Aemilia Ferrara in foveis in quibus Cannabis } \\
\text { maceratur, prope urbem frequens; exicc.: Flora Italica Exsiccata Series II. } \\
\text { Adr. Fiori et A Béguinot. }\end{array}$ \\
\hline & $\begin{array}{l}7303 \\
\text { Lgib2 }\end{array}$ & $\begin{array}{l}\text { coll.: C. Cedercreutz G. Aberg (26.07.1933.); t.s.: Alandia, par. Föglö, } \\
\text { Klävskär, Östra Gregeskläppen, in aquula in monte juxta mare. cfr.n. 553, } \\
\text { 1100; exsicc.: Plantae Finlandiae Exsiccatae Museo botanico Universitatis } \\
\text { Helsingforsiensis distributae. }\end{array}$ \\
\hline & $\begin{array}{l}66829 \\
\text { Lgib3 }\end{array}$ & $\begin{array}{l}\text { coll.: E. Țopa (22.07.1938.); t.s.: Moldava distr. Łaşi. In stagnis ad vicum } \\
\text { Ungheni una cum L. minor alt. cca. } 65 \text { msm.; exsicc.:Flora Romaniae } \\
\text { Exiccatat. }\end{array}$ \\
\hline \multirow{4}{*}{$\begin{array}{l}\text { Wolffia arrhiza (L.) } \\
\text { Hork ex Wimm. }\end{array}$} & $\begin{array}{l}0721118 \\
\text { Warr1 }\end{array}$ & $\begin{array}{l}\text { coll.: K. Fiala (27.09.1962); t.s.: Moravia merid, Distr. Břeclav, in stagno } \\
\text { alvei vetusti ad ripam dextram fluiminis Dyje meridiem versus a pago } \\
\text { Pasohlávsky, cca. } 180 \text { m. s. m. una cum Spirodella polyrrhyza et Lemna sp.; } \\
\text { exicc.: Flora exciccata Republicae Socialisticae Čechoslovacae Instituto } \\
\text { Botanico Universitatis J. E. Purkyne, Brno edita. }\end{array}$ \\
\hline & $\begin{array}{l}47460 \\
\text { Warr2 }\end{array}$ & $\begin{array}{l}\text { coll.: Z. Czubiński - F. Krawiec - G. Rafalski (28.05.1935.); t.s.: Wojew. } \\
\text { poznańskie - palat posnaniensis w torfiance na wielkim torfowisku w } \\
\text { Bagnach k. Obornik - Bagna pr. Oborniki in foveis in turfosis; exicc.: Plantae } \\
\text { Poloniae Exsiccatae. }\end{array}$ \\
\hline & $\begin{array}{l}7483 \\
\text { Warr3 }\end{array}$ & $\begin{array}{l}\text { coll.: G. Gola - O. Mattirolo (10.07.1907.); t.s.: loc: Pedemontium - Augustae - } \\
\text { Taurinorum (Torino) Loco dicto Subbioni di cambiano, in aquitrino ad } \\
\text { dexternum latus uriae ferreae quae gennam ducit prope il Casello ferroriario alt } \\
250 \text { m circ.; exicc.: Flora Italica Exsiccata Series II. Adr. Fiori et A Béguinot. }\end{array}$ \\
\hline & $\begin{array}{l}4787 \\
\text { Warr4 }\end{array}$ & $\begin{array}{l}\text { coll.: A Rakoczi (07.08.1897.); t.s.: Prov. Kiew. In aquis Stagnantibus prope } \\
\text { p. Smiela distr. Czerkasy. }\end{array}$ \\
\hline
\end{tabular}

Fig. 6. present the results of PCA anlysis on the samples. The diatom assemblages of the different Lemnaceae species are grouped together in a well defined cluster, however Lemna trisulca forms in a well separated group.

To summarize the above results, it can be concluded that Lemnicola hungarica does not prefer every "Lemna", but it is tightly attached to well definable taxa of the family Lemnaceae (Wolffia and Spirodela). One of the most remarkable results of our study is that Lemnicola hungarica is not the main epiphyte of Lemna trisulca. The diatom Cocconeis placentula was the characteristic epiphyte in the five samples of Lemna trisulca, while Lemnicola hungarica was conspicuously rare (less than $1 \%$ ). In contrast, Lemnicola hungarica was a main component of the diatom assemblages on Sirodela polyrrhyza and on Lemna minor and L. gibba. In addition, Lemnicola hungarica was the dominant epiphyte on the tiny Wolffia arrhiza.

Besides the biogeographical distribution of diatom assemblages of duckweeds some observation was also made on much smaller scale. Solitary Lemna plants (L.minor) were studied by means of scanning electron microscope. It is a well-known fact that the spatial microdistribution of the epiphytic diatoms on the leaf and root of duckweeds is chracteristic and different (Round pers. com.). Within a few millimetres the species richness as well as the diversity changes markedly (e.g. Goldsborough 1993). The diatom assemblages are different on the surface of phyllosphere and on the different parts of the root (Fig. 4.) The intact coating of the bottom of the leaf is covered almost exclusively by Lemnicola hungarica. Moving away from the leaf, along the root, more and more species can penetrate to the uniform coating that consist of Lemnicola. It is supposed that the presence or absence, as well as the position of diatom species on the surfaces must be controlled by some chemical or physicochemical factors (Round pers. com.). To prove the existence of chemical factor, further studies are required. Notwithstanding the composition of duckweed epiphyton looks stable and the species richness is low all over the World. 


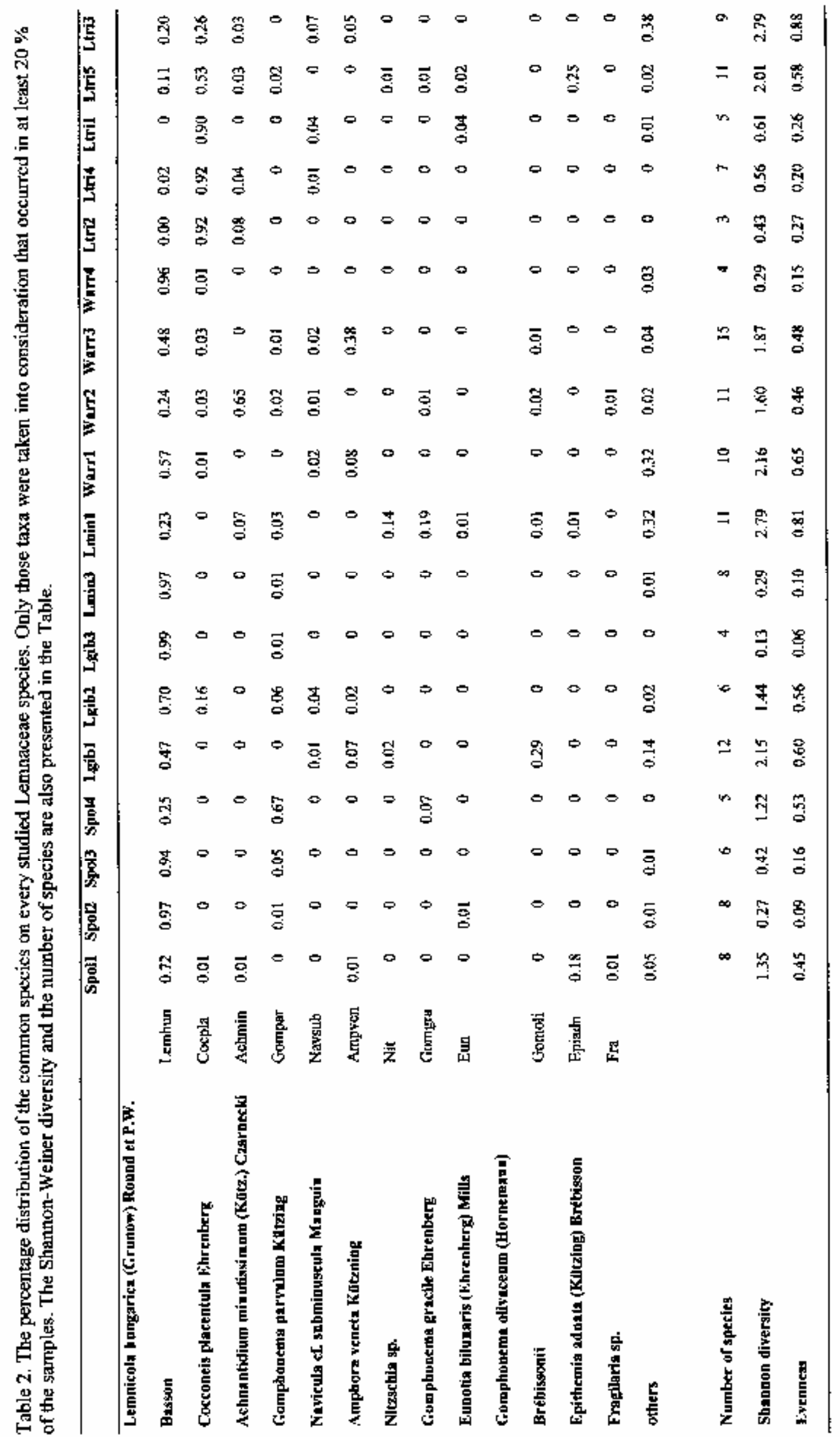



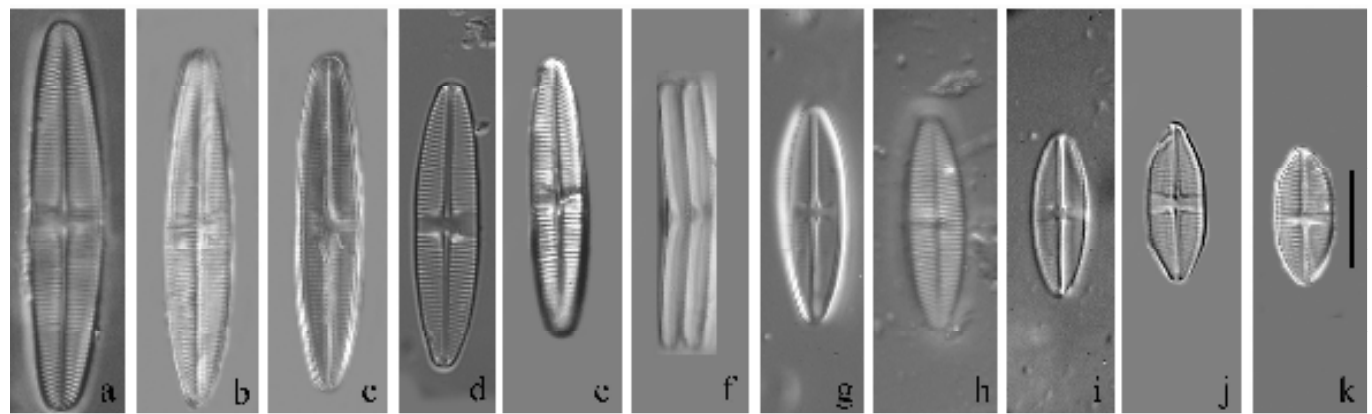

Fig. 2. The morphological variablity of Lemnicola hungarica in light microscope: Figs a-e. and g-k. in valve view; Fig. f. in gridle view. Scale bar is $10 \mu \mathrm{m}$.
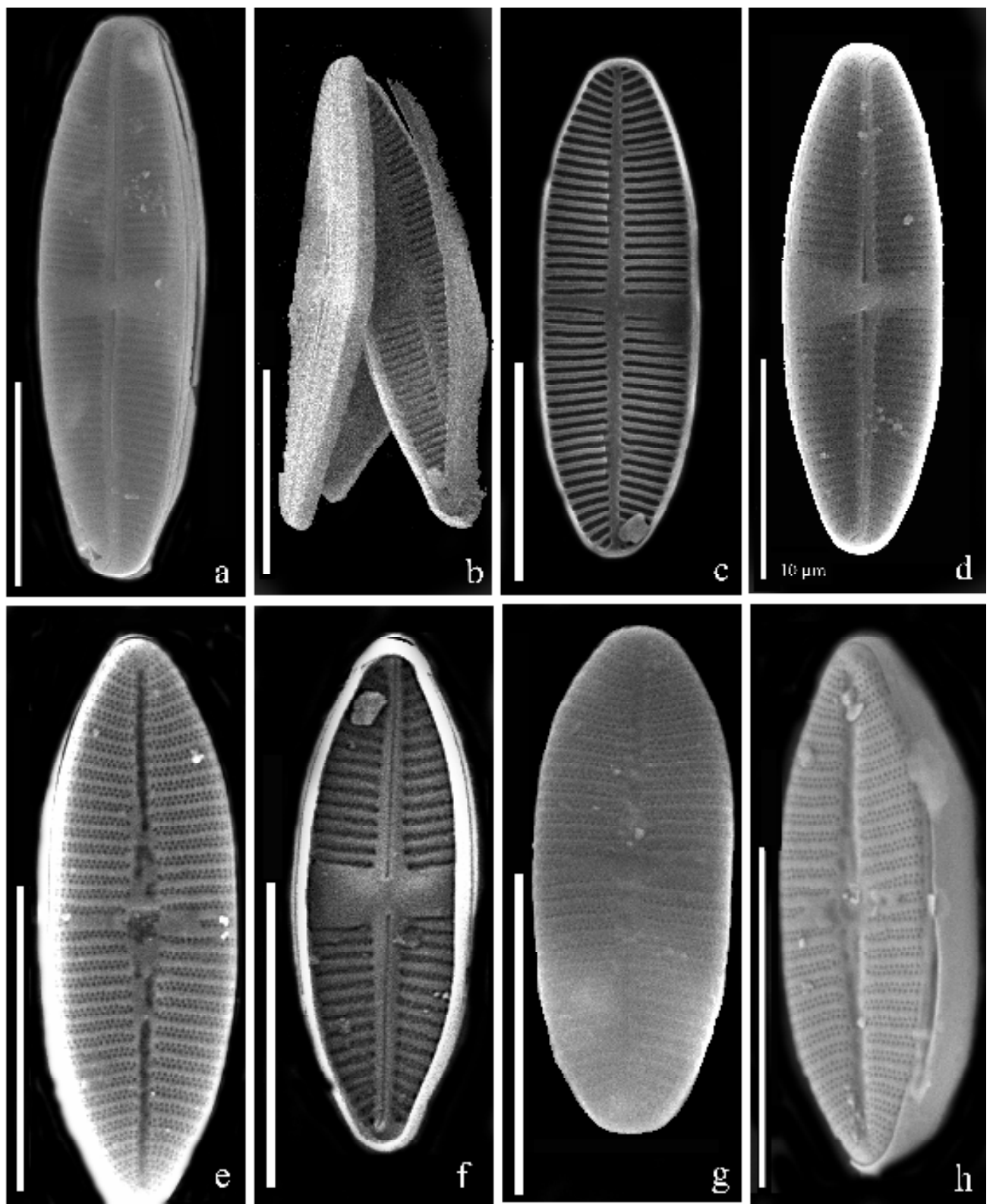

Fig. 3. The SEM pictures of Lemnicola hungarica External view of the raphe valva (a,d), and rapheless valva (g); internal view of raphe (f) and rapheless valva (c); the whole frustule external view (b,h); note an asymmetrical hyaline central area, stauros on the raphe valva, its reduction on rapheless valva and the distal raphe ends curved in opposite directions. Scale bar is $10 \mu \mathrm{m}$. 

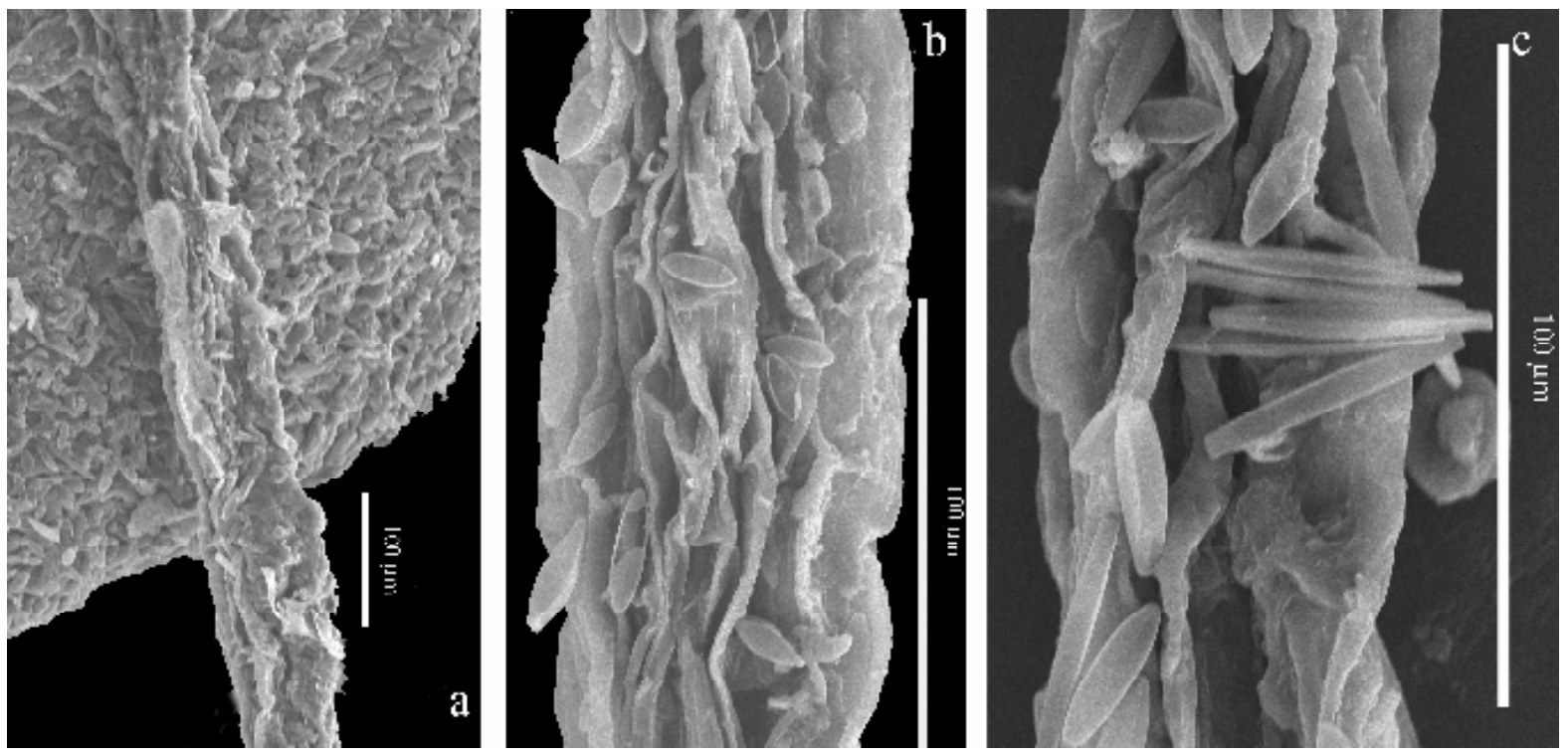

Fig. 4. The spatial microdistribution of the epiphytic diatoms on Lemna minor (SEM, without acid cleaning). The dense coating on the leaf underside is composed of mainly Lemnicola hungarica (a); middle parts of the root surface are inhabited by a diverse assemblage with Gomphonema sp. div. (b), Fragilaria specimens occure on the root tips (c).

During the investigation a probably initial or post-initial valva of Lemnicola hungarica was found. Sexual reproduction has been documented in only a very few diatom species (Round et al. 1990), especially in natural or seminatural conditions (POULÍČKOVÁ \& MANN 2006). Sexual events in diatoms usually need to be studied in diatom clones growing in cultures. (JEWSON \& LOWRY 1993). Nothing has been published on sexual reproduction in Lemnicola hungarica. One initial cell was found in an Italian sample of Sirodela polyrhiza (BP 47394 Flora Italica Exsiccata, Fig. 7). This initial valva has more rounded shape than the vegetative cells, almost twice as long $(70 \mu \mathrm{m})$ as the average length of cells. Note the irregular striae pattern on Fig. 7. Only one such valva was observed during within more than 10000 vegetative Lemnicola valves. Otherwise, the sexual reproduction of diatoms nowadays is in the focus of research because of their potential use in nanotechnology (TIFFANY 2005).

Results of research on the coexistence of Lemnicola hungarica and the duckweed species may provide useful data in the palaeolimnological reconstruction of ponds and lakes. Accumulation of Lemnicola in the sediment layers can be an evidence of the origin of organic matter in sediment (POULíčKOVÁ et al. 2005). Further research on the occurrence and distribution of Lemnicola should be focused on autecology in context to eutrophication and changes in countryside (forests exploitation).
Finally, these data would greatly assist work on vegetational historical reconstructions.

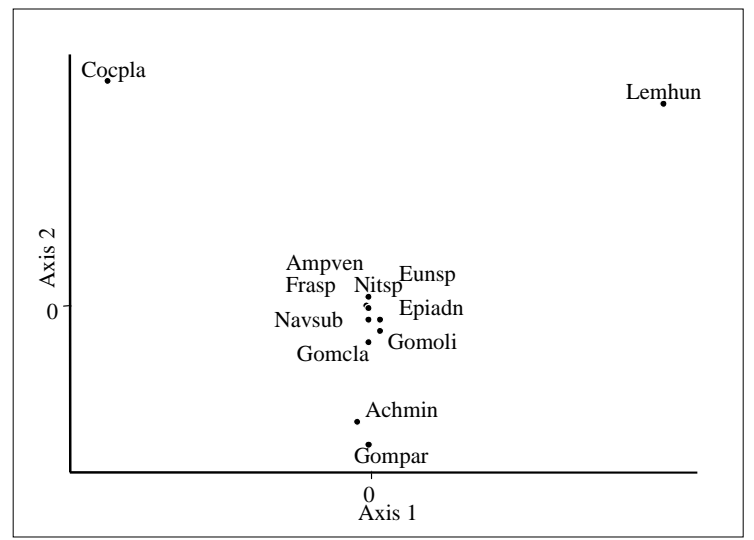

Fig. 5. The result of PCA analysis (diatom species abbreviations see Tab. 2).

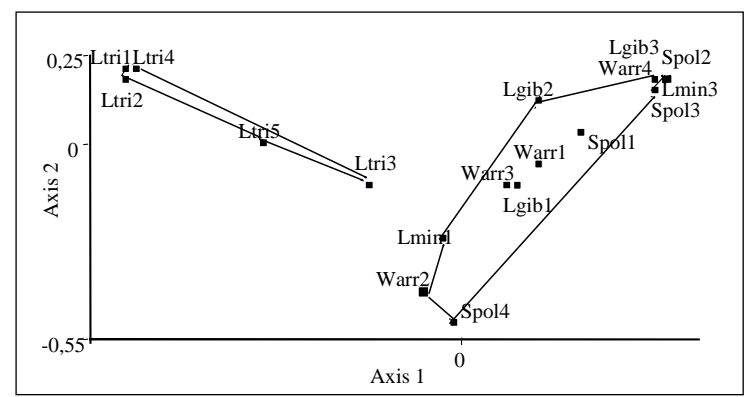

Fig. 6. Ordination diagram of sample scores (PCA). (Ltri Lemna trisulca, Lgib - Lemna gibba, Lmin - Lemna minor, Spol - Sirodela polyrrhiza, Warr - Wolffia arrhiza) 


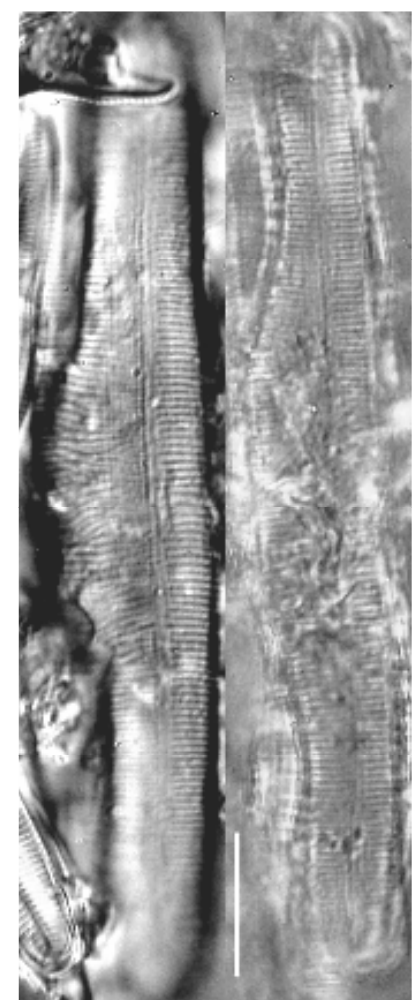

Fig. 7. Initial or post-initial valva of Lemnicola hungarica

\section{Acknowledgements}

This study was sponsored by the Hungarian Scientific Research Fund OTKA (grant number T43078). Dániel Pifkó helped me in the using of Herbarium Generale material. We are grateful to Prof. Frank Round for useful and valuable comments and suggestions.

\section{References}

Garcia, M. \& Fonseca de SouzA, V. (2006): Lemnicola hungarica (GRUNOW) ROUND \& BASSON from Southern Brazil: ultrastructure, plastid morphology and ecology. - Diatom Research 21: 465-471.

GoldsBorough, L.G. (1993): Diatom ecology in the phyllosphere of the common duckweed (Lemna minor L.). - Hydrobiologia 269/270: 463-471.

GRUNOW, A. (1863): Über einige neue and unbekannten Arten und Gattungen von Diatomaceen. Verhandlungen der Kaiserlich-königlich Zoologisch-Botanischen Gesellschaft in Wien, 13: 137-162.

Hustedt, F. (1930): Bacillariophyta (Diatomeaea), Heft. 10. Die Süsswasserflora von Mitteleuropas. - 466. pp., G. Fischer, Jena.

JEwson, D.H. \& Lowry, S. (1993): Cymbellonitzschia diluviana HusTEDT (Bacillariophyceae): Habitat and auxosporulation. - Hydrobiologia 269/270: 87-96.

KRAMMER， K. \& LANGE-BerTALOT, H. (1986-1991): Süsswasserflora von Mitteleuropa. Bacillariophyceae 1-4. - Gustav Fischer Verlag, Stuttgart, Jena.
LANGe-Bertalot, H. (1993): 85 Neue Taxa und über 100 weitere neu definierte Taxa ergänzend zur Süsswasserflora von Mitteleuropa vol. 2/1-4. Bibliotheca Diatomologica 27: $454 \mathrm{pp}$.

PODANI J. 2001: SYN-TAX 2000. u Computer Programs for data analysis in ecology and systematics Users's mManual. - 53 pp., Scientia, Podani J., Budapest.

PoulíčKOVÁ, A., LysÁKOVÁ, M., HAŠLER, P. \& ČEHOVSKÁ, P. (2005): Fishpond sediments - the source of information and algal ,seed bank“. - Book of Abstrakt, Shallow lakes 2005, Dalfsen, p 53.

PoulíčKovÁ, A. \& MANN, D.G. 2006): Reproduction in Navicula cryptocephala (Bacillariophyceae). - 20. Treffen Deutschsprachiger Diatomologen mit internationaler Beteiligung 23.-26. März 2006 in Třeboň Abstracts p. 23.

Round, F. E. \& BAsson, P. W. (1997): A new monoraphid diatom genus (Pogoneis) from Bahrain and the transfer of previously described species $A$. hungarica \& A. taeniata to new genera. - Diatom Research 12: 71-81.

Round, F.E., CRAWFord, R.M. \& MANN, D.G. (1990): The diatoms. - Cambridge univ. Press NY.

Tiffany, M.A. (2005): Diatom Auxospore Scales and Early Stages in Diatom Frustule Morphogenesis: Their Potential for Use in Nanotechnology. Journal of Nanoscience and Nanotechnology 5: 131-139.

(C) Czech Phycological Society (2007)

Received December12, 2006

Accepted February 27, 2007 
